\title{
Field bean for forage and grain in short-season rainfed Mediterranean conditions
}

\author{
Marco Mariotti, ${ }^{1}$ Victoria Andreuccetti, ${ }^{1}$ Iduna Arduini, ${ }^{2}$ Sara Minieri, ${ }^{1}$ Silvia Pampana ${ }^{2}$ \\ ${ }^{1}$ Department of Veterinary Science, University of Pisa; ${ }^{2}$ Department of Agricultural, Food and Agro- \\ Environmental Sciences, University of Pisa, Pisa, Italy
}

\begin{abstract}
The research was carried out to evaluate the growth rate, the evolution of the nutrient characteristics, and the best stage to obtain the highest yield of nutrients from field bean (Vicia faba var. minor Beck) sown in spring for forage and seed. The best models for quanti-qualitative parameter estimation were curvilinear, such as the one proposed by Hoerl with type $\mathrm{y}=\mathrm{A} x^{\mathrm{B}} e^{\mathrm{C} x}$, and linear, using the sum of the growing degree days (GDD) as the climatic variable. The lengths of both the whole biological cycle and the individual phases of the field bean cycle were related to the amount of GDD of the growing environment and were not affected by the cultivation year. Forage dry matter and nutrient yield of the field bean followed a curvilinear model, while the main quality characteristics followed a linear model over the measured GDD. The highest nutrient and forage yields were not reached at the same time. The highest crude protein, total digestible nutrients and forage dry matter (DM) yields were obtained, at approximately 1230, 1290 and 1360 GDD respectively, when the plants were at stages from the pods being visible in the middle of inflorescence to the end of the pod development. The varieties used in this study presented a similar precocity but a very different productivity. Italian varieties, of which Scuro di Torrelama was the best, produced more than the French variety. With the most productive variety, almost $7 \mathrm{t} / \mathrm{ha}$ of forage DM, almost $1.2 \mathrm{t} / \mathrm{ha}$ of $\mathrm{CP}$ and more than $1.3 \mathrm{t} / \mathrm{ha}$ of TDN were obtained. At the GDD of maximum forage production, the CP concentration of the field bean varied from 16 to $18 \%$, EE from 0.6 to $0.7 \%$, NDF from 56 to
\end{abstract}

Correspondence: Marco Mariotti, Department of Veterinary Science, University of Pisa, viale delle Piagge 2, 56124 Pisa, Italy.

E-mail: marco.mariotti@unipi.it

Key words: Field bean; forage yield; grain yield; nutrients yield; quality.

Received for publication: 22 September 2017.

Revision received: 23 January 2018.

Accepted for publication: 27 January 2018.

(C) Copyright M. Mariotti et al., 2018

Licensee PAGEPress, Italy

Italian Journal of Agronomy 2018; 13:1112

doi:10.4081/ija.2018.1112

This article is distributed under the terms of the Creative Commons Attribution Noncommercial License (by-nc 4.0) which permits any noncommercial use, distribution, and reproduction in any medium, provided the original author(s) and source are credited.
$58 \%$, RFV from 83 to $94 \%$, TDN from 41 to $48 \%$, and NEL from 1.0 to $1.2 \mathrm{Mcal} \mathrm{kg}^{-1}$. The effects of advanced or delayed harvests, compared to those carried out at the maximum yield stage, are discussed. Grain yield, which reached a maximum of $1.9 \mathrm{t} / \mathrm{ha} \mathrm{DM}$, $0.56 \mathrm{t} \mathrm{CP} /$ ha and $1.5 \mathrm{t} \mathrm{TDN} /$ ha, was mainly limited by a reduced seed filling stage.

\section{Introduction}

Field bean (Vicia faba L. var. minor Beck) is grown worldwide as an alternative protein source to soybean for feed, (Jezierny et al., 2010), but also for green forage, hay, silage, or green manure (Onofrii and Tomasoni, 1989; Fraser et al., 2001; Borreani et al., 2009). The role of field bean is becoming increasingly important in low-input cropping systems designed to reduce mineral fertilizer inputs (Sulas et al., 2013) and associated $\mathrm{N}_{2} \mathrm{O}$ emissions and fossil fuel consumption (Jensen et al., 2012). This is because it has a greater ability to enrich the soil of nitrogen (through biological $\mathrm{N}_{2}$ fixation) compared with other legume crops (Walley et al., 2007). Field bean also facilitate diversification of the agroecosystem, i.e. planned biodiversity over time, via diversified crop rotations (Jensen et al., 2010), and space, via intercropping (Mariotti et al., 2011). This thus indirectly enhances soil fertility, productivity, and system stability, as well as the resilience of the entire agroecosystems (Kopke and Nemecek, 2010).

In the Mediterranean climate, the sowing date for the field bean generally falls in the autumn. However, the actual time of the autumn sowing is crucial: if done too early, the plants may die due to the following cold winter, and if late, the plants will start to grow in the following spring, negating the effects of advance sowing. Moreover, the excess autumn rains typical of many areas of the north and central Italy often prevent autumn sowing and the field bean has thus to be sown in the spring.

In Italy, research on the forage and seed production by field bean sown in spring is scarce. In Spain, Confalone et al. (2010) reported a reduction in growth cycles from 165 to 93 days and a reduction in grain yield of about $26 \%$, between the autumn-winter and spring sowings.

Some authors (Caballero 1989; Fraser et al., 2001) have reported that the optimal harvesting stage to obtain the highest forage yield is when the pods in the lower inflorescences are fully developed in size (stage 78 of Stülpnagel's scale - 1984). However it is not clear if the reduction in growth cycles caused by the delayed sowing from autumn to spring also modifies the optimal harvesting stage to obtain the highest forage yield. In addition, the maximum forage yield, the maximum nutrients yield and the maximum forage quality probably not coincide, as usually occur in 
other forage crops; however, to the best of our knowledge, no data are available for field bean to establish a precise relationship between these characteristics and the plant growth.

The objectives of the present work were: i) to study the growth rate and the evolution of the nutrient characteristics of the field bean sown for forage and seed in spring; ii) to determine the best stage to obtain the highest production of nutrients per unit area; and iii) to evaluate the genotypic differences between varieties widely used in the Mediterranean area.

\section{Materials and methods}

The research was carried out in 2009 and 2010 at the experimental station of the Department of Agricultural, Food and Environmental Science of the University of Pisa, Italy, which is located at a distance of approximately $10 \mathrm{~km}$ from the sea $\left(43^{\circ} 41^{\prime}\right.$ $\mathrm{N}, 10^{\circ} 23^{\prime} \mathrm{E}$ ) and $1 \mathrm{~m}$ asl. The climate is hot, humid Mediterranean with mean annual maximum and minimum daily air temperatures of $20.2^{\circ}$ and $9.5^{\circ} \mathrm{C}$, respectively, and a precipitation of $971 \mathrm{~mm}$, $37 \%$ of which fall in autumn (Moonen et al., 2001). During the experiment and the growth cycle of the field bean, the total rainfall was $319 \mathrm{~mm}$ in 2009 and $317 \mathrm{~mm}$ in 2010, with a mean temperature of 16.1 and $15.5^{\circ} \mathrm{C}$, respectively.

In both years, treatments were four field bean varieties, three of Italian origin, Chiaro di Torrelama $(\mathrm{CH})$, Scuro di Torrelama (SC), Vesuvio (VE), and the fourth of French origin, Irena (IR). Harvests were carried out at five stages: at the first flower racemes in bloom (stage 61 of the Stülpnagel scale, 1984), at complete flowering (stage 69), when the pods are visible in the middle inflorescences (stage 74), when the first pods lose the green colour (stage 81 ), and when the seeds in the upper pods are completely hard (stage 92).

In both years, the experiment was arranged in a split-plot design with three replicates. Variety was the main plot factor, and harvest stage was the subplot factor. Sub-plot dimensions were 3 by $4 \mathrm{~m}$, each separated by $2 \mathrm{~m}$.

Plants were grown in rows spaced $30 \mathrm{~cm}$ apart. Sowing took place on 4 March 2009 and 26 February 2010 at densities equivalent to 40 viable seeds $\mathrm{m}^{-2}$. Seeding rates used for field bean reflected rates used normally in the region. Field bean was fertilized with nitrogen, phosphorus, and potassium, applied pre-planting as urea, triple mineral phosphate, and potassium sulphate at a rate of $15 \mathrm{~kg} \mathrm{ha}^{-1}$ of $\mathrm{N}, 50 \mathrm{~kg} \mathrm{ha}^{-1}$ of $\mathrm{P}$, and $60 \mathrm{~kg} \mathrm{ha}^{-1}$ of $\mathrm{K}$. Nitrogen was applied as a starter dose to prevent the nutritive deficiency that could occur under water and thermal stress condition (Jensen et al., 2010; Di Paolo et al., 2015). The research was carried under rainfed conditions. Weed control was achieved with a post-emergence application of Propaquizafop and Imazamox.

At each harvest, forage yield was determined by weighing crop biomass harvested from $1 \mathrm{~m}^{2}$, cutting the plants at $5 \mathrm{~cm}$ aboveground level.

One half of the biomass harvested was used for chemical analysis and the rest was separated into leaves, stems, inflorescences (or pods), and, in stage 92, seeds. All samples were oven dried at $70^{\circ} \mathrm{C}$ to constant weight in order to determine the dry matter (DM) yield. Chemical analyses were performed on the entire biomass (leaves, stems and inflorescences) except for the final harvest, in which the chemical analyses were performed separately on the seeds and residues (leaves, stems and pod walls). The parameters analyzed were the concentrations of crude protein (CP), ash, ether extract (EE), neutral-detergent fiber (NDF), acid-detergent fiber
(ADF) and acid-detergent lignin (ADL), according to Martillotti et al. (1987). Forage quality was estimated by the relative feed value (RFV), an index calculated by ADF (related to dry matter digestibility), and NDF (related to intake potential).

The following equations were used to estimate the RFV and total digestible nutrients (TDN), as described by Aydin et al. (2010), while net energy for lactation (NEL) was estimated through the equation proposed by Horrocks and Vallentine (1999):

$$
\begin{aligned}
& \text { RFV }=(88.9-(0.77 \times \mathrm{xDF} \%)) \times(120 / \mathrm{NDF} \%) \times 0.775 \\
& \mathrm{TDN}(\%)=(1.291 \times \mathrm{xDF} \%)+101.35 \\
& \text { NEL }(\mathrm{Mcal} / \mathrm{kg})=(1.044-(0.0119 \times \mathrm{xAF} \%)) \times 2.205
\end{aligned}
$$

In the seeds, non-fibrous carbohydrate (NFC) was estimated as $\mathrm{NFC}=100-(\mathrm{NDF} \%+\mathrm{CP} \%+\mathrm{EE} \%+\mathrm{Ash} \%)$.

The CP, NDF and TDN yields per unit area were calculated by multiplying the yield per hectare and the CP, NDF and TDN concentrations.

Results were subjected to analysis of variance using CoStat version 6.4 (CoHort Software, Berkeley, CA, USA). The effects of year, variety, harvest stage and their interaction were analyzed using a split-split-plot design with year designed as whole plot, variety as sub-plots, and harvest stage as sub-sub-plots. Significantly different means were separated at the 0.05 probability level by the least significant difference test (Steel et al., 1997). ANOVA revealed no significant differences between years or Year $\times$ Variety $\times$ Harvest interaction, Year $\times$ Variety interaction and Year $\times$ Harvest interaction for all the parameters measured. The results were thus averaged over the two years.

Changes in field bean and qualitative parameters were evaluated by calculating the relationship between yield and qualitative parameters against time and growing degree days (GDD). GDD were calculated with the NOAA method, assuming $1.7^{\circ} \mathrm{C}$ as the base temperature (Iannucci et al., 2008). Linear, quadratic and Hoerl equations were tested to describe the relationship between parameters and time/GDD. The Hoerl function of type $\mathrm{y}=\mathrm{A} x^{\mathrm{B}} e^{\mathrm{C} x}$ was used, where $y$ is yield or qualitative parameter, $x$ is accumulated GDD, and A, B, C are regression constants. This function, which combines a power and exponential relationship, has already been used in similar experiments and generally in plant science (Singh et al., 1996; Paparozzi et al., 2005). The equation with the highest determination coefficient $\left(\mathrm{R}^{2}\right)$ and the smallest standard error of estimate was selected as the most appropriate (Hair et al., 1995). All regression analyses were performed using ten pairs of $x$, $\mathrm{y}$ values (five sampling dates for each of the two years, and the mean sampling value over the two years are presented in graphs). For the curvilinear relationships, the first derivative was computed to define the maximum value reached by the curve and the time/GDD corresponding to the maximum value (Bullock and Bullock, 1994).

\section{Results}

The growth stages of field bean at harvest are reported in Table 1. About twenty days from sowing and 190 GDD were needed for the plant emergence $\left(T_{\text {base }} 1.7^{\circ} \mathrm{C}\right.$; Iannucci et al., 2008). Field bean completed the growth cycle three months after sowing and after about 1800 GDD accumulated. No appreciable differences among varieties were detected regarding the GDD required to complete the phenological stages.

The code of the growth stage of field beans, as reported in the 
Stülpnagel scale (1984), was linearly related with the increase in the number of days and the accumulation of GDD from sowing. However, GDD were more appropriate than the number of days to represent the change in growth stage (i.e. the linear regression coefficient was higher for GDD than for days from sowing). Therefore, regardless of the variety, from the stage of first flower racemes in bloom (code 61) onwards, the code increased linearly by about three stages every 100 GDD accumulated (Figure 1).

\section{Forage production}

The increase by weight of the field bean forage, expressed as a function of the sum of GDDs, showed reduced differences between the two years, and thus can be represented by a single equation. This confirms that GDD provides a sufficiently precise index of all the climatic elements that affect the growth of field bean (Yoldas and Esiyok, 2009).

The yield variation of field bean forage, as a function of accumulated GGD, was best represented by the Hoerl equation (Figure 2), and the coefficient of determination was very high for all the varieties $\left(\mathrm{R}^{2} \geq 0.94^{* *}\right)$.

Forage yield increased to about 1300-1400 GDD, and thereafter decreased (Figure 2 and Table 2). The highest forage yield of field bean and the stage in which the maximum yield was reached varied between the varieties: SC presented the highest value (more than $6 \mathrm{t} / \mathrm{ha}$ ) and IR, the lowest (just under $4 \mathrm{t} / \mathrm{ha}$ ). IR and $\mathrm{CH}$ varieties were the earliest, because they reached the maximum yield when the pods were visible in the upper inflorescences (stage 77), after accumulating about 1320 GDD, while VE was the latest (end of pod development, stage 79, 1391 GDD).

The same model was the best to describe the relationship between the GDD and the dry matter forage concentration (Figure 2). The equation parameters did not differ significantly regarding the four varieties, thus a single equation was sufficient to represent them all. At the GDD of the maximum yield, the DM concentration was $20 \%$ in $\mathrm{CH}$ and IR, $22 \%$ in SC and $24 \%$ in VE.

During the growth cycle, the DM distribution in different plant parts of field bean (leaves, stems and inflorescences) changed appreciably (Figure 3). The leaves decreased from 50 to less than $10 \%$, the inflorescences increased from less than 10 to about $40 \%$, while the stems remained stable from $40 \%$ to $50 \%$ (data not shown). The SC variety always presented the lowest percentage of leaves and the highest percentage of inflorescences, while the opposite occurred in VE (Figure 3). At the stage of maximum yield for each variety, SC presented a $21 \%$ leaf proportion and a $38 \%$ inflorescence proportion, while IR and VE presented more leaves (26\%) and fewer inflorescences (about 31\%).

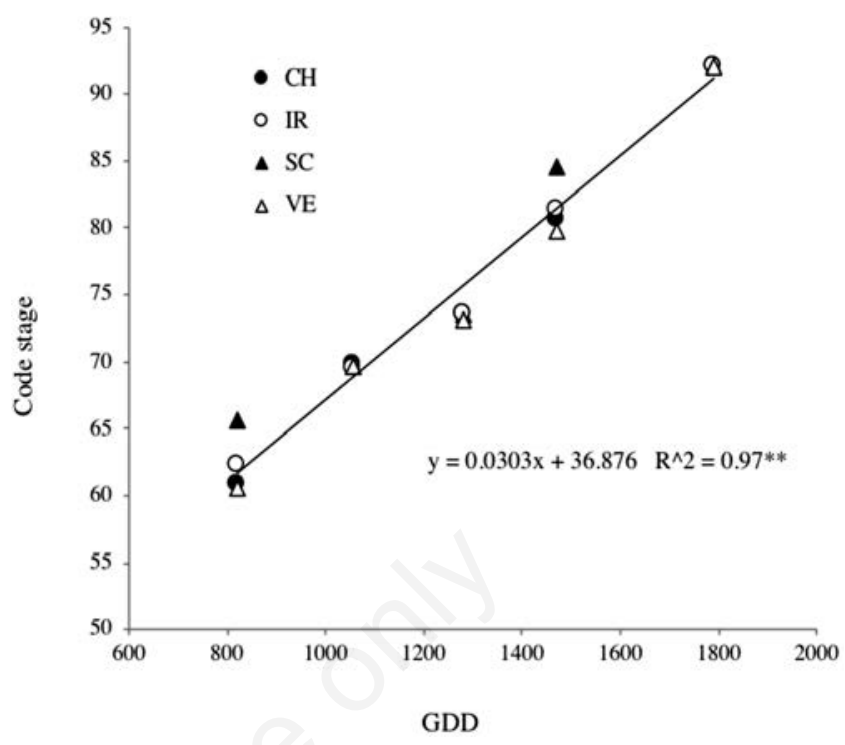

Figure 1. Relationship between the code stage of field bean (Stiilpnagel, 1984) and the accumulated growing degree days (GDD). CH, Chiaro di Torrelama; IR, Irena; SC, Scuro di Torrelama; VE, Vesuvio. Values are the means of two years and three replicates.

Table 1. Main growth stages of field bean and corresponding number of days after sowing and number of growing degree days.

\begin{tabular}{lccc} 
Growth stage & Code stage* & DAS & GDD \\
Sowing (Dry seed) & 01 & 0 & 0 \\
Emergence & 10 & 21 & 191 \\
\hline First flower racemes in bloom & 61 & 71 & 820 \\
Flowering complete & 69 & 84 & 1056 \\
\hline Pods visible in the middle inflorescences & 74 & 96 & 1280 \\
First pod looses green color & 81 & 106 & 1472 \\
\hline Ripeness complete & 92 & 121 & 1791 \\
\hline
\end{tabular}

*Stülpnagel's scale (1984). DAS, days after sowing; GDD, growing degree days.

Table 2. Maximum values and corresponding growing degree days (GDD) plus code stage obtained by field bean varieties calculated with the quadratic equations between accumulated GDD and yields of dry matter, crude protein, neutral detergent fiber and total digestible nutrients.

\begin{tabular}{|c|c|c|c|c|c|}
\hline \multirow[t]{2}{*}{ Character } & \multirow[t]{2}{*}{ Parameter } & \multicolumn{4}{|c|}{ Variety } \\
\hline & & $\mathrm{CH}$ & IR & SC & VE \\
\hline $\mathrm{DM}\left(\mathrm{g} \mathrm{m}^{-2}\right)$ & $\begin{array}{c}\text { Max value } \\
\operatorname{GDD}\left(\text { Stage }^{\circ}\right)\end{array}$ & $\begin{array}{c}462.7^{\mathrm{b} *} \\
1328(77)\end{array}$ & $\begin{array}{c}370.5^{\mathrm{a}} \\
1311(77)\end{array}$ & $\begin{array}{c}659.6^{\mathrm{c}} \\
1359(78)\end{array}$ & $\begin{array}{c}516.7^{\mathrm{b}} \\
1391(79)\end{array}$ \\
\hline CP $\left(\mathrm{kg} \mathrm{ha}^{-1}\right)$ & $\begin{array}{c}\text { Max value } \\
\text { GDD (Stage) }\end{array}$ & $\begin{array}{c}947.0^{\mathrm{b}} \\
1205(73)\end{array}$ & $\begin{array}{c}781.9^{\mathrm{a}} \\
1186(73)\end{array}$ & $\begin{array}{c}1168.2^{c} \\
1245(75)\end{array}$ & $\begin{array}{c}1005.3^{b} \\
1298(76)\end{array}$ \\
\hline NDF $\left(\mathrm{kg} \mathrm{ha}^{-1}\right)$ & $\begin{array}{c}\text { Max value } \\
\text { GDD (Stage) }\end{array}$ & $\begin{array}{c}2669.1^{\mathrm{b}} \\
1382(79)\end{array}$ & $\begin{array}{c}2123.2^{\mathrm{a}} \\
1354(78)\end{array}$ & $\begin{array}{c}4106.5^{\mathrm{d}} \\
1393(79)\end{array}$ & $\begin{array}{c}3053.8^{c} \\
1435(80)\end{array}$ \\
\hline TDN $\left(\mathrm{kg} \mathrm{ha}^{-1}\right)$ & $\begin{array}{c}\text { Max value } \\
\text { GDD (Stage) }\end{array}$ & $\begin{array}{c}2240.1^{\mathrm{b}} \\
1262(75)\end{array}$ & $\begin{array}{c}1792.3^{\mathrm{a}} \\
1261(75)\end{array}$ & $\begin{array}{c}2844.6^{c} \\
1303(76)\end{array}$ & $\begin{array}{c}2170.4^{\mathrm{b}} \\
1312(77)\end{array}$ \\
\hline
\end{tabular}

CH, Chiaro di Torrelama; IR, Irena; SC, Scuro di Torrelama; VE, Vesuvio; DM, dry matter; CP, crude protein; NDF, neutral detergent fiber; TDN, total digestible nutrients. *In a row, values followed by the same letter are not significantly different, for $\mathrm{P} \leq 0.05$; ${ }^{\circ}$ Stülpnagel's scale (1984). 


\section{Quality characteristics}

The CP concentration of forage decreased linearly with the increase in GDD accumulated by the field bean (Figure 4). The magnitude of the decrease (slope of regression) was almost the same in CH, IR and SC (about $-1.5 \%$ for each 100 GDD accumulated) and substantially lower in VE $(-0.9 \%)$. Accordingly, at about 800 GDD (stage 61), the CP forage concentration was the same in all varieties (about 25\%), while from about 1400 GDD (stage 79) onwards, VE presented a higher CP concentration than the other varieties (Figure 4).

The EE and ash concentration decreased linearly as the GDD increased. The ANOVA indicated that there were no statistical differences among the varieties, thus the EE and ash concentrations of the forage can be represented for all the varieties by the following linear equations: $\mathrm{EE}=1.54-0.00071 \mathrm{x}\left(\mathrm{R}^{2}=0.96^{* *}\right)$; Ash $=$ $10.10-0.0017 \mathrm{x}\left(\mathrm{R}^{2}=0.88^{* *}\right)$ (data not shown). The EE and ash concentrations showed a low variation throughout the increase in
GDD: from 800 to $1800 \mathrm{GDD}$, values changed from 0.9 to $0.3 \%$ for the EE and from 10 to $8 \%$ for the ash concentration (data not shown).

NDF and ADF concentrations showed a linear increase with GDD accumulated by field bean $\left(0.89^{* *} \leq \mathrm{R}^{2} \leq 0.99^{* *}\right)$. The SC variety showed the highest concentration in both parameters, while IR showed the lowest. The NDF and ADF rate increase ranged respectively from 1.5 to $1.9 \%$ and from 1.1 to $1.4 \%$ every 100 GDD accumulated (Figure 4).

The ADL concentration in the forage of field bean and between the varieties did not change appreciably with the increase in GDD, showing an average value of $12 \%$ (data not shown).

The relative feed value decreased linearly during the growth cycle from values higher than $100 \%$ at about 800 GDD (stage 61), to $65-75 \%$ at 1800 GDD (stage 92 ). SC always presented the lowest value (from 106 to 64\%), while IR and $\mathrm{CH}$ presented the highest values (from about 116 to $73 \%$ ).
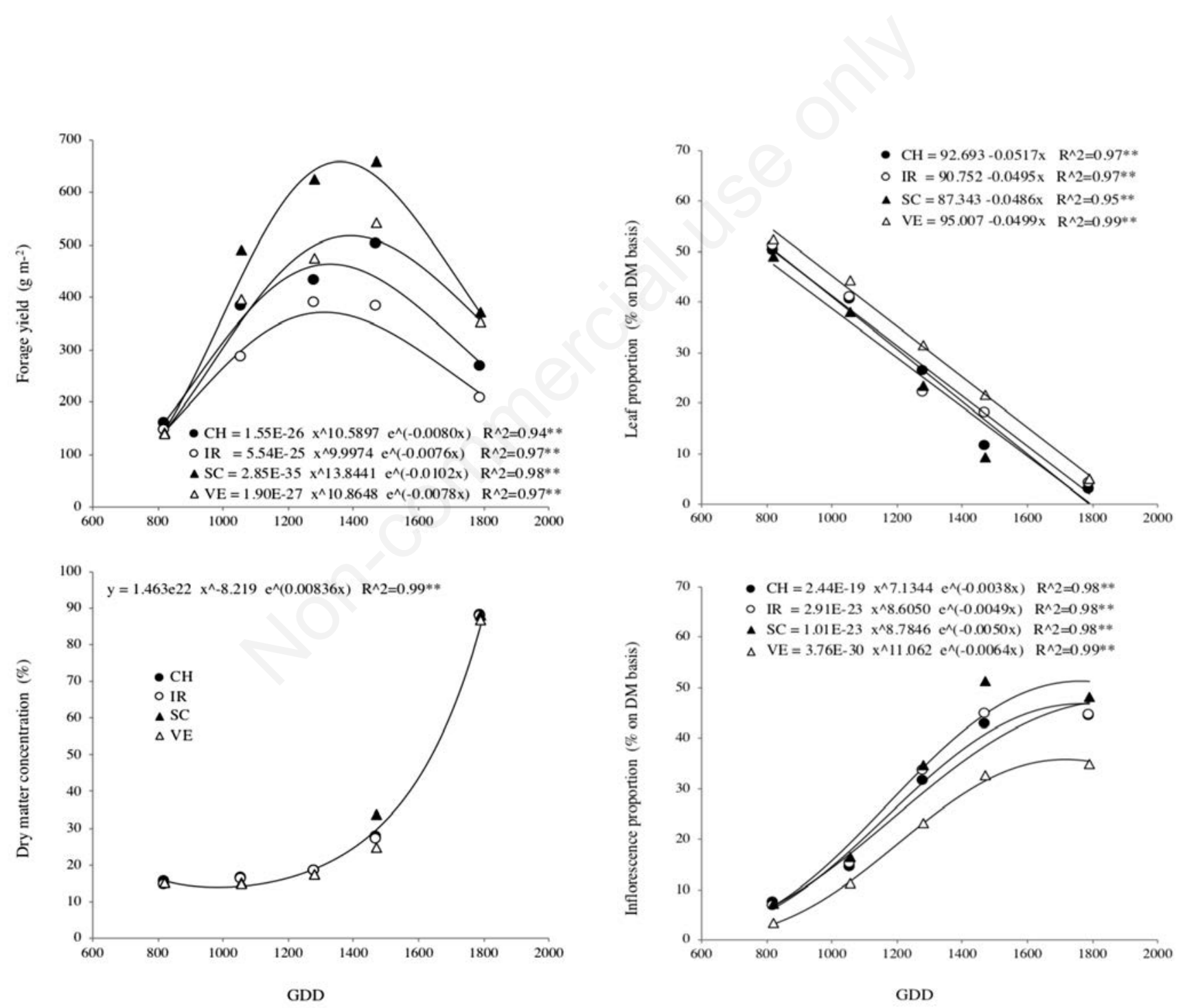

Figure 2. Relationship between the forage dry matter (DM) yield, the forage DM concentration and the accumulated growing degree days (GDD). CH, Chiaro di Torrelama; IR, Irena; SC, Scuro di Torrelama; VE, Vesuvio. Values are the means of two years and three replicates.

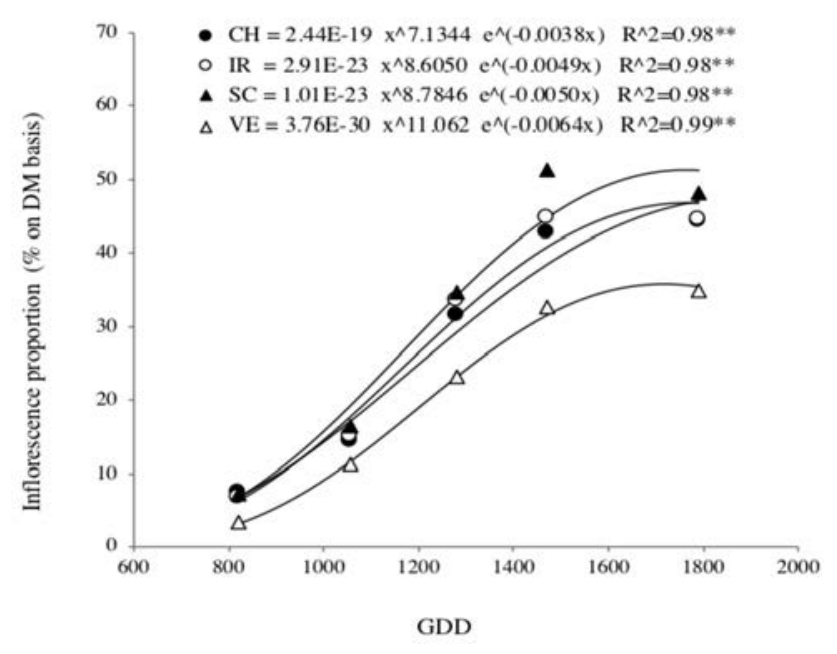

Figure 3. Relationship between the leaf and inflorescence proportion $[a s \%$ of the total dry matter (DM)] and the accumulated growing degree days (GDD). CH, Chiaro di Torrelama; IR, Irena; SC, Scuro di Torrelama; VE, Vesuvio. Values are the means of two years and three replicates. 
The TDN concentration and the NEL showed a linear decrease with the increase in GDD. The average decrease in TDN ranged from $53 \%$ to about $35 \%$, and the decrease in NEL from 1.32 to $0.96 \mathrm{Mcal} / \mathrm{kg}$. Regarding varieties and for both parameters, IR showed the highest values, while SC and VE showed the lowest. The rate of decrease (regression slope) was appreciably lower for the IR than for the other varieties (Figure 4)

The main quality characteristics of the field bean forage were highly positively correlated with the leaf proportion, regardless of the variety or the cultivation year (Figure 5). With the increase in age of the plants, with every $10 \%$ decrease in leaf proportion, the CP, RFV and TDN decreased by $2.5,8.4$ and $3.1 \%$, respectively.
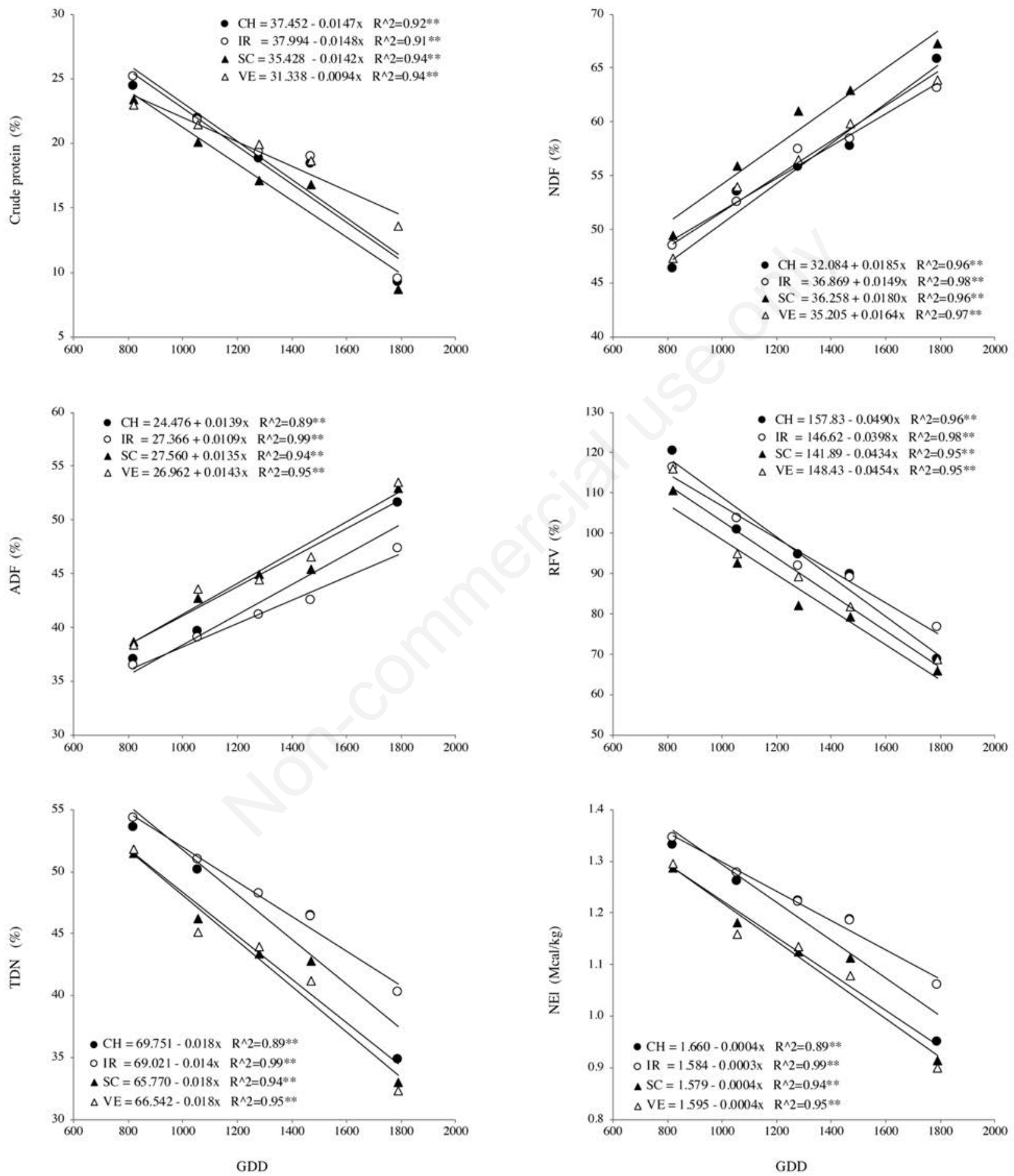

Figure 4. Relationship between the concentrations of crude protein (CP), neutral-detergent fiber (NDF), acid-detergent fiber (ADF), relative feed value (RFV), total digestible nutrients (TDN), net energy for lactation (NEL) and the accumulated growing degree days (GDD). CH, Chiaro di Torrelama; IR, Irena; SC, Scuro di Torrelama; VE, Vesuvio. Values are the means of two years and three replicates. 


\section{Nutrient yield}

The Hoerl model was the best at representing the relationship between GDD and production per unit area of CP, NDF and TDN by field bean (Figure 6).

The maximum CP yield was obtained at around 1200-1300 GDD, between the 73 (pods visible in the lower inflorescences) and 76 (pods visible in the upper inflorescences) growth stages (Figure 6). The most productive variety was SC (about $1170 \mathrm{~kg} \mathrm{CP}$ $\mathrm{ha}^{-1}$ ) and the lowest productive variety was IR, with a $49 \%$ difference between both (Table 2).

The NDF yield of field bean increased to about 1400 GDD and subsequently decreased (Figure 5). IR was found to be the earliest variety (maximum NDF yield at stage 78) and VE the latest variety (stage 80 ) (Table 2). The maximum yield was obtained by SC and the minimum by IR with a $93 \%$ difference between both.

The TDN yield increased to about 1300 GDD (stages 75-77) with the highest values reached by SC $(2.8 \mathrm{t} / \mathrm{ha})$ and lowest by IR (1.8 t/ha) (Table 2).

\section{Seed yield and quality}

Grain yield and the main characteristics of grain production are reported in Table 3.

The highest grain yield was obtained by SC $\left(192 \mathrm{~g} / \mathrm{m}^{2}\right)$ and the lowest by IR $\left(111 \mathrm{~g} / \mathrm{m}^{2}\right)$. The highest yield shown by SC was due to the greater number of pods per plant and the higher 1000 seed weight than the other varieties.

The nutrient concentration of the seeds ranged between the varieties from 28 productive variety to $33 \% \mathrm{CP}$, from 30 to $36 \%$ of NDF, and from 26 to $37 \%$ of NFC, while TDN was about $78 \%$ for all (Table 3). VE presented the highest crude protein and NDF concentration, but a lower NFC concentration, while the opposite was found for $\mathrm{CH}$.

The nutrient yield of grain was always highest in SC and lowest in IR. In terms of SC about $550 \mathrm{~kg} \mathrm{CP} \mathrm{ha}^{-1}, 670 \mathrm{~kg} \mathrm{NDF} \mathrm{ha}^{-1}$ and $1500 \mathrm{~kg} \mathrm{TDN} \mathrm{ha}^{-1}$ were obtained (Table 3).

Table 3. Grain yield and quality of the four field bean varieties. Values are the means of two years and three replicates.

\begin{tabular}{|c|c|c|c|c|}
\hline \multirow[t]{2}{*}{ Character } & \multicolumn{4}{|c|}{ Variety } \\
\hline & $\mathrm{CH}$ & IR & SC & VE \\
\hline DM yield $\left(\mathrm{g} \mathrm{m}^{-2}\right)$ & $135.7^{\mathrm{b} *}$ & $111.4^{\mathrm{a}}$ & $192.1^{\mathrm{c}}$ & $127.5^{\mathrm{b}}$ \\
\hline Pods (n plant ${ }^{-1}$ ) & $6.9^{b}$ & $4.1^{\mathrm{a}}$ & $8.3^{c}$ & $8.7^{c}$ \\
\hline Seeds (n pod ${ }^{-1}$ ) & $2.4^{\mathrm{a}}$ & $2.8^{\mathrm{a}}$ & $2.3^{\mathrm{a}}$ & $2.3^{\mathrm{a}}$ \\
\hline Mean seed w. (mg) & $190.3^{b}$ & $214.3^{\mathrm{bc}}$ & $231.0^{c}$ & $146.3 \mathrm{a}$ \\
\hline PG (\%) & $27.8^{\mathrm{a}}$ & $29.0^{\mathrm{ab}}$ & $29.0^{\mathrm{ab}}$ & $32.5^{\mathrm{b}}$ \\
\hline EE (\%) & $0.71^{\mathrm{a}}$ & $0.72^{\mathrm{a}}$ & $0.69^{\mathrm{a}}$ & $0.86^{\mathrm{b}}$ \\
\hline Ash (\%) & $3.99^{\mathrm{b}}$ & $4.07^{\mathrm{b}}$ & $3.82^{\mathrm{a}}$ & $4.02^{b}$ \\
\hline NDF (\%) & $30.4^{\mathrm{a}}$ & $35.4^{\mathrm{b}}$ & $35.1^{\mathrm{b}}$ & $36.2^{\mathrm{b}}$ \\
\hline $\mathrm{ADF}(\%)$ & $17.2^{\mathrm{a}}$ & $19.4^{b}$ & $17.7^{\mathrm{ab}}$ & $18.0^{\mathrm{ab}}$ \\
\hline ADL (\%) & $2.06^{\mathrm{a}}$ & $2.54^{\mathrm{ab}}$ & $2.83^{\mathrm{b}}$ & $2.68^{b}$ \\
\hline NFC (\%) & $37.1^{\mathrm{c}}$ & $30.8^{\mathrm{ab}}$ & $31.4^{\mathrm{ab}}$ & $26.4^{\mathrm{a}}$ \\
\hline TDN (\%) & $79.2^{\mathrm{a}}$ & $76.3^{\mathrm{a}}$ & $78.5^{\mathrm{a}}$ & $78.1^{\mathrm{a}}$ \\
\hline $\mathrm{CP}\left(\mathrm{kg} \mathrm{ha}^{-1}\right)$ & $377.2^{\mathrm{b}}$ & $323.1^{\mathrm{a}}$ & $557.1^{\mathrm{c}}$ & $414.4^{b}$ \\
\hline NDF $\left(\mathrm{kg} \mathrm{ha}^{-1}\right)$ & $412.5^{\mathrm{ab}}$ & $394.5^{\mathrm{a}}$ & $674.4^{c}$ & $461.6^{b}$ \\
\hline TDN $\left(\mathrm{kg} \mathrm{ha}^{-1}\right)$ & $1074.7^{\mathrm{b}}$ & $850.3 \mathrm{a}^{\mathrm{a}}$ & $1508.4^{\mathrm{c}}$ & $996.0^{\mathrm{b}}$ \\
\hline
\end{tabular}

\section{Discussion and conclusions}

From the beginning of the bloom onwards, the phenological stages of the field bean sown in spring, encoded with Stülpnagel (1984) scale digits, followed a linear positive trend with the accumulated GDD, with no differences between the two years and the
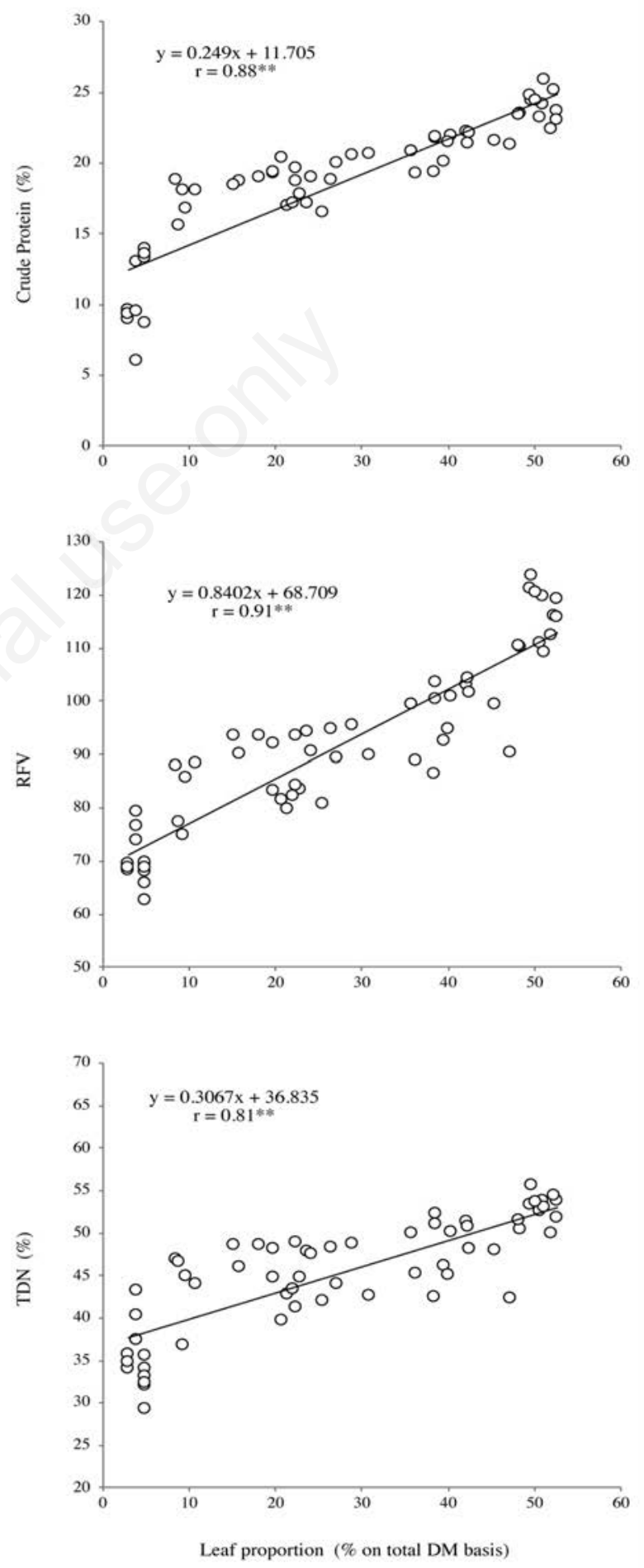

Figure 5. Correlation between crude protein, relative feed value (RFV), total digestible nutrients (TDN), and the leaf proportion $[$ as $\%$ of the total dry matter (DM)]. 
four varieties. To complete the flowering stage (code stage 69), the field bean required little more than 1000 GDD, almost the same value recorded by Iannucci et al. (2008), although they sowed field bean in the autumn.

Forage dry matter and nutrient yield of the field bean followed a curvilinear model over the measured GDD as there was an increase from about 800 to 1200-1400 GDD, and a decrease thereafter. In contrast, the main bromatological characteristics followed a linear model over the measured GDD.

The highest forage yield was reached at the end of the pod development (code stage 78), after the accumulation of about 1360 GDD. The differences in the precocity among the varieties were very low, IR was slightly earlier than the others, and VE, slightly later. On the other hand, the choice of variety was a very important factor in maximizing the yield: from the end of the full blossom phase (about 1000 GDD, stage 67), the SC variety produced a significantly higher forage yield than the others. The yield obtained with the most productive variety exceeded $6 \mathrm{tha}^{-1}$, which was similar to that obtained in the Mediterranean area sowing the field bean in autumn (Caballero, 1989; Colombari et al., 2006; Borreani et al., 2009). In general, from the first flower to the maturity stages, the quality of the field bean forage declined linearly as the accumulated GDD increased. The CP concentration decreased from 25 to $12 \%$, EE from 1 to $0.3 \%$, RFV from 112 to $69 \%$, TDN from 51 to $44 \%$ and NEL from 1.3 to $0.9 \mathrm{Mcal} \mathrm{kg}^{-1}$. In the same period NDF increased from 49 to $66 \%$, and ADF from 37 to $50 \%$. The modifications in the forage quality during the growth cycle of field bean are in relation to the morphological plant changes, and especially with the fall and senescence of the leaves.

At the highest forage production (code stages 77-79), the CP concentration of the field bean varied from 16 to $18 \%$ among the four varieties: $\mathrm{EE}$ from 0.6 to $0.7 \%$, NDF from 56 to $58 \%$, RFV from 83 to $94 \%$, TDN from 41 to $48 \%$, and NEL from 1.0 to 1.2 Mcal $\mathrm{kg}^{-1}$. The highest nutrient yield was achieved earlier, while the maximum NDF yield occurred later than the maximum forage yield. With regard to crude protein, the maximum yield was obtained when the pods were visible in the middle inflorescences (stage 74, 1234 GDD). With the most productive variety (SC), a little less than $1.2 \mathrm{t} /$ ha of CP was obtained, in line with findings in the Mediterranean area by Caballero (1989), and Dordas and Lithourgidis (2011).

Considering the TDN, the maximum yield, corresponding to a little less than $3 \mathrm{t} / \mathrm{ha}$ for the SC variety, was obtained just before the maximum forage DM yield, i.e. when the pods were visible in the upper inflorescences (stage 76), after accumulating about 1285 GDD. Our models can be used to estimate whether any production losses occur by harvesting the forage in stages other than those of maximum yield. Thus, if the forage was harvested with the highest $\mathrm{CP}$ production, the loss of forage DM would reach a maximum of $5 \%$ among the different varieties. In addition, if the forage was harvested with the maximum TDN production, the loss of forage DM would be at most $2 \%$. On the other hand, if the forage was harvested at the time of the highest forage DM yield, there would be a lower CP production of $7 \%$ and TDN of $2 \%$, compared to the maximum possible.

The forage of field bean can be ensiled. However, the high moisture content at cutting makes the crop unsuitable for direct ensiling and thus requires a wilting period, in order to prevent poor fermentation and the production of effluent (Borreani et al., 2009). At the maximum forage yield of $\mathrm{CP}$ and DM, the dry matter concentration of the field bean was respectively 17 and $22 \%$ in all varieties. In both cases, wilting is necessary, but our equations can be used to estimate when the forage should be harvested to elimi- nate this. Considering a target value of $30 \%$ DM, such harvesting should be carried out at about 1480 GDD, thus when the first pods lose their green colour (stage 82). If the forage is harvested at this
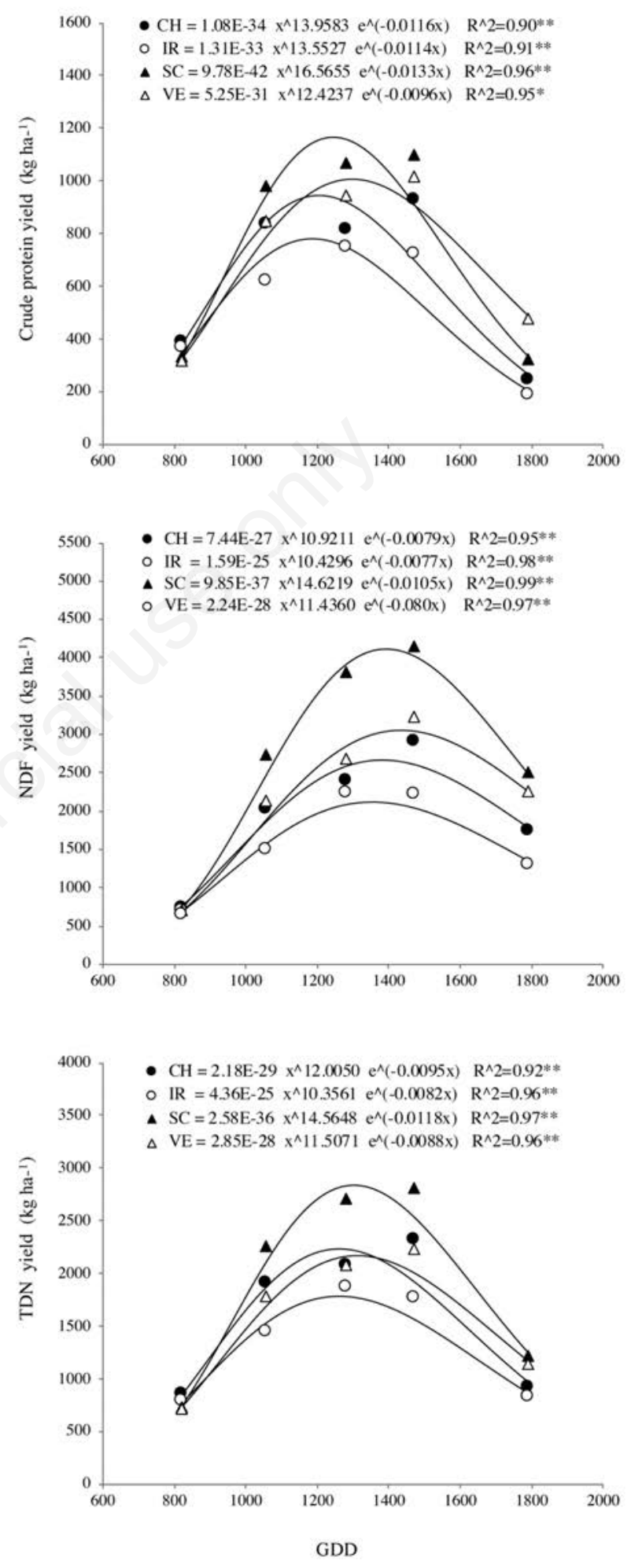

Figure 6. Relationship between the yields of crude protein, neutraldetergent fiber (NDF), total digestible nutrients (TDN) and the accumulated growing degree days (GDD). CH, Chiaro di Torrelama; IR, Irena; SC, Scuro di Torrelama; VE, Vesuvio. Values are the means of two years and three replicates. 
stage, the DM yield loss, compared to that obtained at the maximum forage yield, would be low (up to 6\%). However, $\mathrm{CP}$ and TDN losses would be high both in terms of concentration (about $20 \%$ for $\mathrm{CP}$ and $-8 \%$ for TDN) and yield ( $-30 \% \mathrm{CP}$ and $-15 \%$ TDN, respectively). Thus, abandoning the wilting by delaying the harvest would lead to low DM losses, but high quality losses.

The Italian varieties produced more than the French variety (IR), which was therefore the least suitable for spring sowing. However, IR was found to have a better quality than the others, in relation to the higher leafiness and the lower fibre accumulation.

In summary, the spring sowing of the field bean obtained a sufficiently high forage production and the optimal harvesting stage ranged from 74 to 78 , depending on whether the highest nutrients or DM yield is preferred. The seed yield of the field bean was in line with other studies carried out on field bean sown in the spring (Battini et al., 2001; Moschini et al., 2014). Among the production characteristics, the average weight of the seeds was rather low, probably because sowing delays may have exposed the plants to high temperatures and water stress (Flores et al., 2013). As a result, the grain nutrient production was also considerably smaller than that obtained with the forage (about half) and smaller than that estimated by Annicchiarico (2017) to match the economic value of a relevant cereal benchmark crop. Consequently, the spring sowing of the field bean seems more suitable for forage than for seed production.

\section{References}

Annicchiarico P, 2017. Feed legumes for truly sustainable cropanimal systems. Ital. J. Agron. 12:151-60.

Aydin N, Mut Z, Mut H, Ayan D, 2010. Effect of autumn and spring sowing dates on hay yield and quality of oat (Avena sativa L.) genotypes. J. Animal Vet. Adv. 9:1539-45.

Battini F, Ligabue M, Marmo N, 2001. Pisello proteico e favino da granella, alternative per soia e farine proteiche. L'Inf. Agr. 14:61-5.

Borreani G, Revello Chion A, Colombini S, Odoardi M, Paoletti R, Tabacco E, 2009. Fermentative profiles of field pea (Pisum sativum), faba bean (Vicia faba) and white lupin (Lupinus albus) silages as affected by wilting and inoculation. Anim. Feed Sci. Technol. 151:316-23.

Bullock DG, Bullock DS, 1994. Quadratic and quadratic- plus plateau models for predicting optimal nitrogen rates of corn: A comparison. Agron. J. 86:191-5.

Caballero R, 1989. Yields and chemical composition of wholecrop field beans and their components during pod-filling. Grass Forage Sci. 44:347-51.

Colombari G, Crovetto GM, Loatelli L, Preus P, 2006. Il favino da foraggio al Nord. L'Inf. Agr. 9:61-6.

Confalone A, Lizaso JI, Ruiz-Nogueira B, López-Cedrón FX, Sau F, 2010. Growth, PAR use efficiency, and yield components of field-grown Vicia faba L. under different temperature and photoperiod regimes. Field Crops Res. 115:140-5.

Di Paolo E, Garofalo P, Rinaldi M, 2015. Irrigation and nitrogen fertilization treatments on productive and qualitative traits of broad bean (Vicia faba var. minor L.) in a Mediterranean environment. Legume Res. 38:209-18.

Dordas CA, Lithourgidis AS, 2011. Growth, yield and nitrogen performance of faba bean intercrops with oat and triticale at varying seeding ratios. Grass Forage Sci. 66:569-77.

Flores F, Hybl M, Knudsen JC, Marget P, Muel F, Nadal S, Narits L, Raffiot B, Sass O, Solis I, Winkler J, Stoddard FL, Rubiales
D, 2013. Adaptation of spring faba bean types across European climates. Field Crops Res. 145:1-9.

Fraser MD, Fychan R, Jones R, 2001. The effect of harvest date and inoculation on the yield, fermentation characteristics and feeding value of forage pea and field bean silages. Grass Forage Sci. 56:218-30.

Iannucci A, Terribile MR, Martiniello P, 2008. Effects of temperature and photoperiod on flowering time of forage legumes in a Mediterranean environment. Field Crops Res. 106:156-62.

Jensen ES, Peoples MB, Hauggaard-Nielsen H, 2010. Faba bean in cropping systems. Field Crops Res. 115:203-16.

Jensen ES, Peoples MB, Boddey RM, Gresshoff PM, HauggaardNielsen H, Alves BJR, Morrison MJ, 2012. Legumes for mitigation of climate change and the provision of feedstock for biofuels and biorefineries. A review. Agron. Sustain. Dev. 32:329-64.

Jezierny D, Mosenthin R, Bauer E, 2010. The use of grain legumes as a protein source in pig nutrition: A review. Anim. Feed Sci. Technol. 157:111-28.

Hair J, Anderson R, Tatham R, Black W, 1995. Multivariate data analysis with readings. Prentice-Hall International, Inc., NJ, USA.

Horrocks RD, Vallentine JF, 1999. Harvested Forages. Academic Press, London, UK, pp 1-315.

Köpke U, Nemecek T, 2010. Ecological services of faba bean. Field Crops Res. 115:217-33.

Mariotti M, Masoni A, Ercoli L, Arduini I, 2011. Optimizing forage yield of durum wheat/field bean intercropping through $\mathrm{N}$ fertilization and row ratio. Grass Forage Sci. 67:243-54.

Martillotti F, Antongiovanni M, Rizzi L, Santi E, Bittante G, 1987. Analysis methods to evaluate animal feeds. CNR, IPRA, Rome, Italy.

Moonen C, Masoni A, Ercoli L, Mariotti M, Bonari E, 2001. Longterm changes in rainfall and temperature in Pisa, Italy. Agr. Med. 131:66-76.

Moschini V, Casella G, Vivoli R, Vazzana C, Martini A, Lotti C, Migliorini P, 2014. Performance of organic grain legumes in Tuscany. Ital. J. Agron. 9:38-43.

Onofrii M, Tomasoni C, 1989. Le foraggere coltivate in Italia. Edagricole, Bologna, Italy.

Paparozzi ET, Stroup WW, Conley ME, 2005. How to investigate four-way nutrient interactions in plants: A new look at response surface methods. J. Am. Soc. Hortic. Sci. 130:459-68.

Singh RS, Ramakrishna YS, Joshi NL, 1996. Growth response of mustard [Brassica juncea (L.) Czern \& Coss] to irrigation levels in relation to temperature and radiation regimes. J. Arid Environ. 33:379-88.

Steel RGD, Torrie JH, Dickey DA, 1997. Principles and procedure of statistics. A biometrical approach. McGraw-Hill, New York, USA, pp 1-672.

Sulas L, Roggero PP, Canu S, Seddaiu G, 2013. Potential nitrogen source from field bean for rainfed Mediterranean cropping systems. Agron. J. 105:1735-42.

Stülpnagel R, 1984. Proposal of growth stages for Vicia faba. In: Hebblethwaite PD, Dawkines TCK, Heath MC, Lockwood G (Eds.), Vicia faba: agronomy, physiology and breeding. In: Martinus Nijhof, The Hague, Netherlands, pp 9-14.

Walley FL, Clayton GW, Miller PR, Carr PM, Lafond GP, 2007. Nitrogen economy of pulse crop production in the Northern great plains. Agron. J. 99:1710-18.

Yoldas F, Esiyok D, 2009. The influence of temperature on growth and yield of green beans for processing. Int. J. Agric. Res. 4:124-30. 